\title{
Ecotourism Policy Research Trends in Indonesia, Japan, and Australia
}

\author{
Saraswati Sisriany ${ }^{1 *}$, Katsunori Furuya ${ }^{2}$ \\ 'Graduate School of Horticulture, Department of Environment Science and Landscape Architecture, Chiba University, \\ 648 Matsudo, Matsudo, Chiba, Japan 271-8510 \\ ${ }^{2}$ Landscape Planning of Graduate school of Horticulture, Landscape Architecture Course, Chiba University, \\ 648 Matsudo, Matsudo, Chiba, Japan 271-8510
}

Received February 21, 2020/Accepted July 16, 2020

\begin{abstract}
Numerous definitions and concepts regarding ecotourism lead to different implementations in ecotourism policies and systems. Identifying trends between countries provide valuable information for the development of inadequate ecotourism sites. This study aimed to understand the trends in ecotourism policies in Japan, Indonesia, and Australia by examining the bibliographic records of existing ecotourism policy research. These records were retrieved from the Scopus database and processed by using the scientometrics analysis. The results show the significant research trends of ecotourism policy in each country based on the co-occurrence of keywords were "conservation" for Indonesia, "biodiversity" for Japan, and "management" for Australia. Whereas, based on the research field, it revealed a similar priority within ecotourism policy between Australia and Japan in Social Science, while Indonesia in Environmental Science. The pattern of the keyword network analysis results in an anomaly in Indonesia compared to Japan and Australia, which clarifies the overlapping problem in ecotourism policy in Indonesia. It also visualized the shifting trends of research in some timeline intervals and notifies their relation to the emerging of ecotourism policy. This research also included the usefulness of the research results for future study and the recommendation for the ecotourism policy, especially for Indonesia.
\end{abstract}

Keywords: co-occurrence, cluster analysis, scientometrics, research themes

*Correspondence author, email: saraswatisisriany@gmail.com

\section{Introduction}

Ecotourism has been a widely defined and used concept by researchers and experts from various academic fields. This concept emerged in the 1970s and 1980s in the literature on sustainable development and environmental development, which then caused much enthusiasm for conflicting debates (Fennell, 2015). One of the earliest definitions of ecotourism was as activities of traveling to a nature area that is undisturbed and uncontaminated with a clear objective such as study, pondering, and enjoying the nature view and its wildlife, including the cultural attractions in the area (Ceballos-Lascurain, 1996). Ecotourism has been recently defined as "responsible travel to natural areas that conserves the environment, sustains the well-being of the local people, and involves interpretation and education" (TIES, 2016).

Increasing demand for tourism in the current era of focus on ecological issues has given rise to the need for more ecotourism sites. Respond to this need; almost all countries have increasingly promoted ecotourism. The approaches pursued by each country regarding the promotion of ecotourism have varied, and most countries have conducted ecotourism research based on their own needs, influencing the presence and procedures of the national ecotourism policies.

Australia is an excellent example of ecotourism due to its recognized leadership and rapidly developing ecotourism industry. Australia is one of the pioneers in ecotourism. It has formed an organization named Ecotourism Australia in 1991 that has promoted ecotourism and developed the National Ecotourism Accreditation Program (NEAP) ecotourism standard launched in 1996, which was later renamed Ecotourism Australia with various types of certification.

Japan has a specific policy of ecotourism in Japan that been implemented since 2007 called Ecotourism Promotion Act. The Ecotourism Promotion Council is in charge of organizing ecotourism in Japan, as specified by the national Ecotourism Promotion Act. The council members include local government officials, citizens, and academics, and the Council has links to 17 local institutions that organize ecotourism activities tailored to the local culture and natural sites in their zone (Fukamachi, 2017).

Indonesia, as a country with abundant potential natural resources, the government of Indonesia strongly supports tourism in a variety of ways. The governmental institutions actively promoted ecotourism, including the ministries of 
forestry and environment, marine, tourism, and home affairs. Nevertheless, there is still a lack of integration of proper ecotourism management at the central and regional levels, leading to the uncoordinated development of ecotourism by each party (Meilani \& Muntasib, 2013). Research in regulation and policy aspects is essential for national ecotourism development since the failure of most ecotourism programs is due to the overlapping management and lack of coordination of the sectors responsible for the programs (Nasution et al., 2018). State of the art of the researches and its trend related to regulation and policy in ecotourism development is necessary to be known.

Research trends in ecotourism policy in Indonesia are expected to represent the problems behind ecotourism development policies in Indonesia. Comparing the research trends of Indonesia and other countries that have good ecotourism development policies are expected to explore the policy gaps among them to improve the ecotourism development in Indonesia.

A research trend can be represented by a network of various items such as references, collaborating authors, and co-occurring keywords. Scientometrics is possible to analyze several types of networks from bibliographic sources and used for investigation of the document networks of cooccurring keywords and cluster analysis (Chen, 2018).

This study aimed to understand the trends of ecotourism policies in Indonesia, and in Japan and Australia as the comparison, to understand and overcome a country's problem related to the research trends and its policies in a broader context and point of view, and to identify future research trends and recommendations.

\section{Methods}

Ecotourism policy research trends in Indonesia, Japan, and Australia were analyzed using the Scientometrics approach. Scientometrics is the quantitative study of science using computational and visual analytics to detect and identify patterns and emerging trends of research themes based on existing publications or bibliographic records (Chen et al., 2014). This method has widely applied to various fields such as psychology (Chen et al., 2019), sustainability (Albort-Morant et al., 2017; de Toledo et al., 2019), environmental research (Martinez et al., 2019), city planning (Min, et al., 2019), management (Guo et al., 2017), and agriculture (Hossard \& Chopin, 2019).

Data collection The data were retrieved from Scopus Elsevier scientific database on its website within the period between 1990 and 2019. The documents were specifically for 'ecotourism policy' and selected by using the advanced search option based on the following keywords: TITLE-ABS-KEY (("ecotourism" OR "sustainable tourism" OR "ecotourism" OR "ecotourism") AND ("policy" OR "regulation" OR "strategy" OR "strategies")). Furthermore, a limitation was added to extract the database based on the research affiliation country using the following keywords: AND (LIMIT-TO (AFFIL COUNTRY,"country-name")). All of the selected data were exported into the .ris format by the Scopus export feature for further analysis in the CiteSpace (5.5) software.

Scopus was selected as the database of this research since it has an option to limit the search based on a particular country; this feature was necessary to distinguish data between Indonesia, Japan, and Australia. The other consideration is because it often used as Indonesia's requirement for research publication and brings an additional reputation for Indonesian academicians. As an international journal index, Scopus is most suitable for this research considering its impact factor and standard, although it is limited only for English articles.

Data analysis The selected research database from each country was first analyzed by the Scopus Journal Analyzer that is available on Scopus websites. It shows the research trend of the selected document based on the published year, subject, and document type. The analysis and visualization of the keyword network and cluster used CiteSpace (5.5) software (Chen, 2006).

All collected data were refined and then analyzed by generating a series of co-occurring keywords networks based on the title, abstract, and keywords noun phrase. The cooccurrence keywords are regarded as the co-word relation. The more frequent every two keywords co-occur, the stronger the co-word relation is (Chen \& Morris, 2003). The keyword network analysis visualized by the betweenness centrality degree, which represents the probability of the closest distance in the graph (Chen et al., 2005). The higher the degree, the bigger the word's size in keyword networks, so we can easily recognize the significant co-occurrence keywords, which we interpreted as the 'research trends. Cluster analysis applied to classify the co-occurrence keywords and summarize the essence of the abstracts in bibliographic records into cluster labels, which we interpreted as the 'research themes.

Further examination also conducted based on various indicators as follows: a) the pivot nodes, for intellectual turning points of the research (Chen, 2012), b) silhouettes scores, for the quality of the clusters (Chen et al., 2012), c) cluster labels size, for the importance of research themes, d) time interval for research evolution overtimes, and d) the overall patterns. Both co-occurring keywords and cluster labels in this article were combined into one figure of each country.

\section{Results and Discussion}

According to the bibliography extracted from Scopus, there were 99 ecotourism-related research studies in Indonesia, 35, and 296 studies in Japan and Australia, respectively. The number of ecotourism research in Japan was much lower than in Indonesia. However, the ecotourism research in Japan has been stated earlier and consistently since 2002. In Indonesia, ecotourism policy research just started in the year 2008; however, it increased significantly in the past five years (2015-2019). Meanwhile, Australia has begun research related to ecotourism policy since the early $90 \mathrm{~s}$, with a significant increase in the research effort two decades later (Figure 1). Ecotourism policy research has been conducted in many subject areas. The most often investigated subject area in Japan and Australia was Social Sciences, whereas, for Indonesia, it was Environmental Science (Table 1). Publication related to ecotourism policy in Indonesia was dominated by conference papers $(52,2 \%)$, while in Japan $(67,6 \%)$ and Australia $(83,1 \%)$ were 
dominated by research articles (Figure 2).

Network analysis The trends in ecotourism policy research in Indonesia based on the degree of keyword betweenness results are "conservation", "ecology", "biodiversity", "ecotourism", and "local community". Other issues investigated in ecotourism policy research include "forestry", "sustainable development", "tourism development", "local government", "ecosystem", "planning", and "economics", as shown in Figure 3.

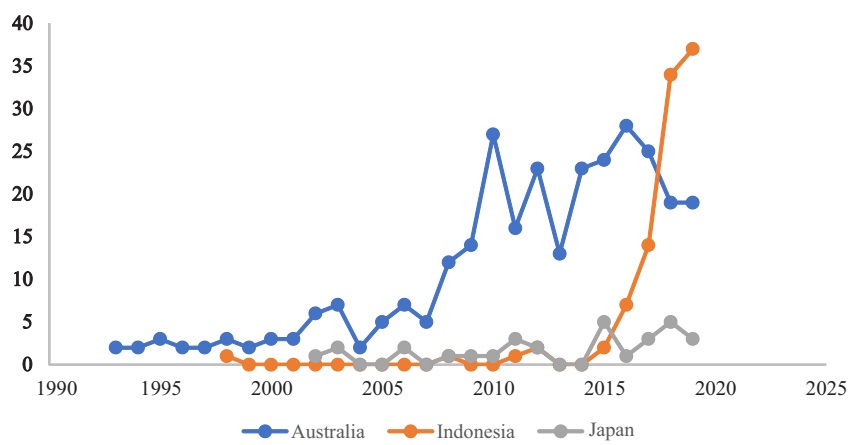

Figure 1 Documents by year.

\section{Japan}

Documents by type

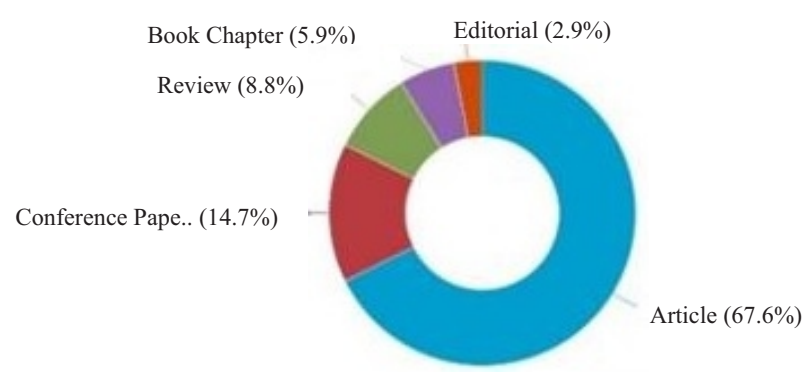

Copyright $\subset 2019$ Elsevier B.V All rights reserved. Scopus $₫$ is registered trademark of Elsevier B.V
Conservation research plays a vital role in the ecotourism policy field since it has the highest betweenness degree and also forms the pivotal points, and connects the timeline nodes from the early to recent studies. Hence, it can be concluded that conservation is the main principle of ecotourism policy in Indonesia. Various subjects of the ecotourism policy research in Indonesia have included carrying capacity conservation area for tourists attraction (Murdiyarso et al., 2015; Aryasa et al., 2017), tourism assessment (Sri Budhi \& Lestari, 2016; Mustika et al., 2017;

Table 1 Top ten subject area of ecotourism policy research

\begin{tabular}{lccc}
\hline \multicolumn{1}{c}{ Subjectarea } & Japan & Indonesia & Australia \\
\hline Environmental science & 13 & 57 & 91 \\
Earth and planetary sciences & 1 & 36 & 15 \\
Social sciences & 18 & 20 & 199 \\
Business, management and accounting & 11 & 19 & 186 \\
Agricultural and biological aciences & 7 & 17 & 49 \\
EnergyPhysics and astronomy & 2 & 9 & 8 \\
Economics, econometrics and finance & - & 7 & - \\
Engineering & 3 & 6 & 24 \\
Computer science & 1 & 6 & 5 \\
\hline
\end{tabular}

\section{Indonesia}

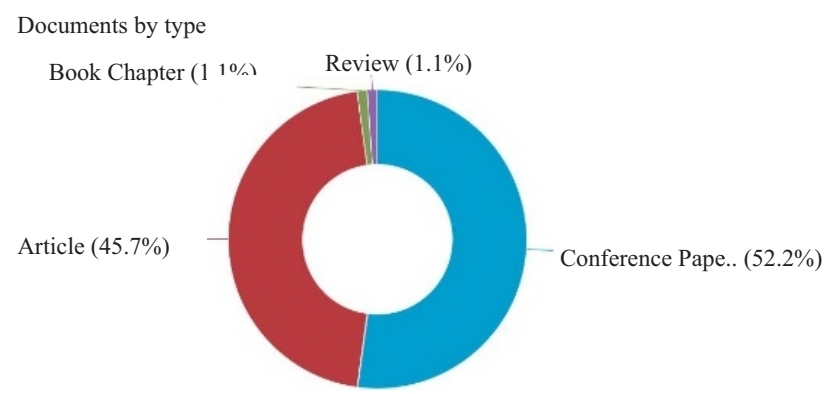

Copyright $\odot 2019$ Elsevier B.V All rights reserved. Scopus $®$ is registered trademark of Elsevier B.V

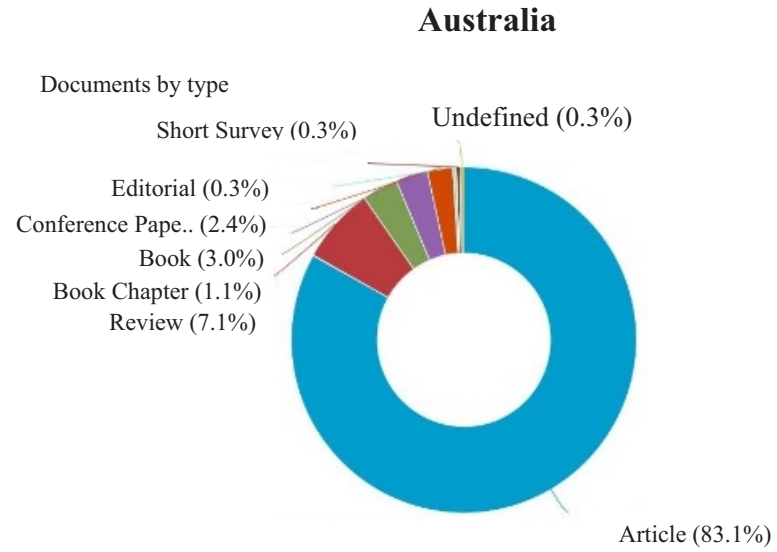

Copyright $(\mathcal{C} 2019$ Elsevier B.V All rights reserved. Scopus $®$ is registered trademark of Elsevier B.V

Figure 2 Document types of ecotourism policy publication in Japan, Indonesia and Australia based on Scopus Index. 
Ariefianda et al., 2019), and management strategy (Wardani et al., 2017; Idajati \& Widiyahwati, 2018; Indah et al., 2018; Sasana et al., 2019). Research studies related to ecotourism policy in Indonesia have mostly focused on a particular area, and have been case study-based rather than nationwide.

In Japan, the highest degree of betweenness centrality values was found for the following keywords: 'biodiversity', 'sustainability', 'Hokkaido', 'participatory approach', and 'heritage tourism'. These were followed by 'conservation', 'china', 'community', 'forestry', 'far east', 'ecosystem service', 'cultural heritage', 'destination management', and 'ecosystem' (Figure 4). The critical turning point of the research trend was identified for three keywords, namely sustainability, heritage tourism, and participatory approach. Research trends shifted from the 2002-2006 time period through the turning points of heritage tourism trends to a participatory approach in 2010 and sustainability in the last five years. The pattern for ecotourism-policy-related research in Japan includes research that focused on the tourism practice in Hokkaido. Various studies in Japan related to ecotourism policies are as follows: understanding of the potential value in tourism destination management to formulate new tourism strategies (Higuchi \& Yamanaka, 2019), marketing policy for ecotourism (João Romão et al., 2014), tourism preferences and demands of ecotourism (Neuts et al., 2016).

In Australia, the trend of ecotourism policy research in Australia, based on the betweenness degree results, is 'management regime', 'management strategy', 'tourism management', 'sustainable tourism', and 'sustainability'. 'Ecotourism' and 'Australia' keywords were excluded as trends since their apparent keywords are related to all ecotourism policy research in Australia and are not considered to indicate trends.

The research trend in Australia has been consistently focused on management. The turning point of the research trend in Australia shifted from focuses on sustainable tourism to investigations of management strategy. Numerous research studies of ecotourism policy related to management strategy cited include environmental impacts management (Turton, 2005), tourist and wildlife (Orams, 1996; Orams \& Hill, 1998; Miller et al., 2004; Schianetz et al., 2009), and cultural impacts (Chin et al., 2000).

Cluster analysis The six clusters were obtained for the ecotourism policy research trend in Indonesia. They are a) Coast People, b) Community based tourism, c) Sumatran Elephant, d) Branding Strategy, e) Whale Shark, and f) Data Collection (Figure 3). Cluster \#0 Coastal People appeared as

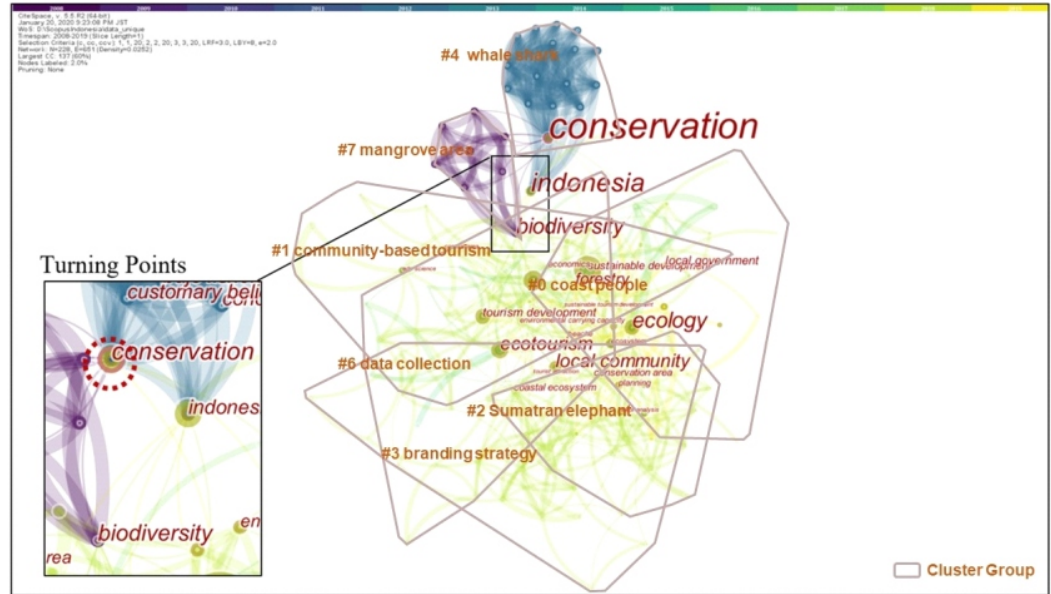

Figure 3 Co-occuring keywords and cluster labels of ecotourism policy research in Indonesia.

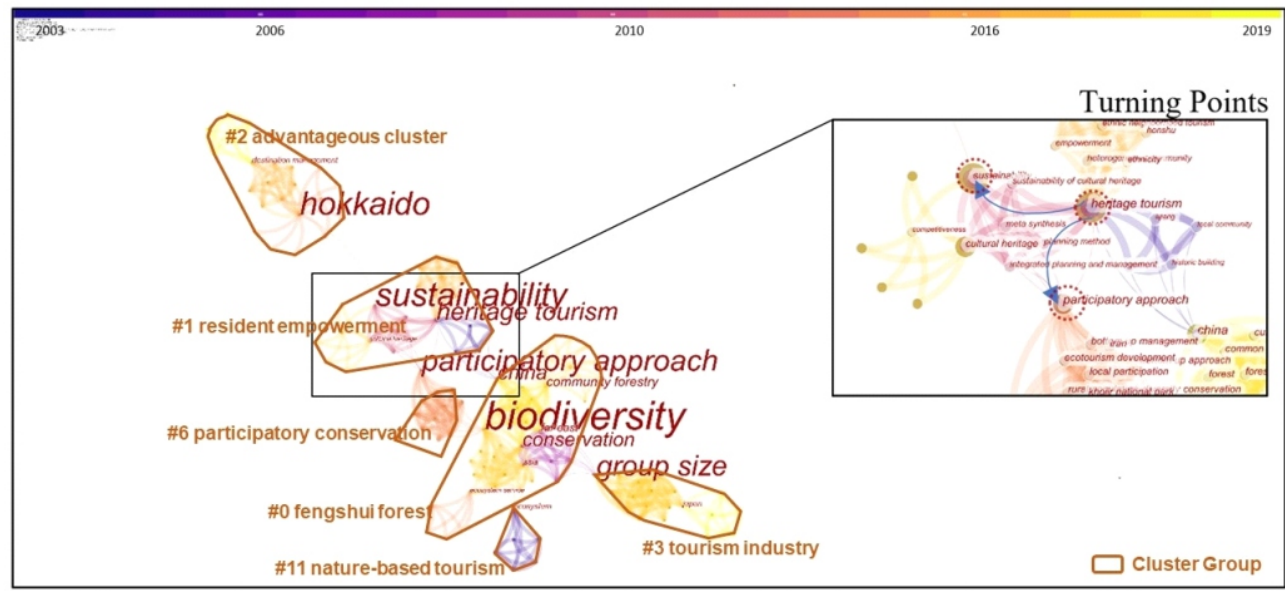

Figure 4 Co-occuring keywords and cluster labels of ecotourism policy research in Japan. 


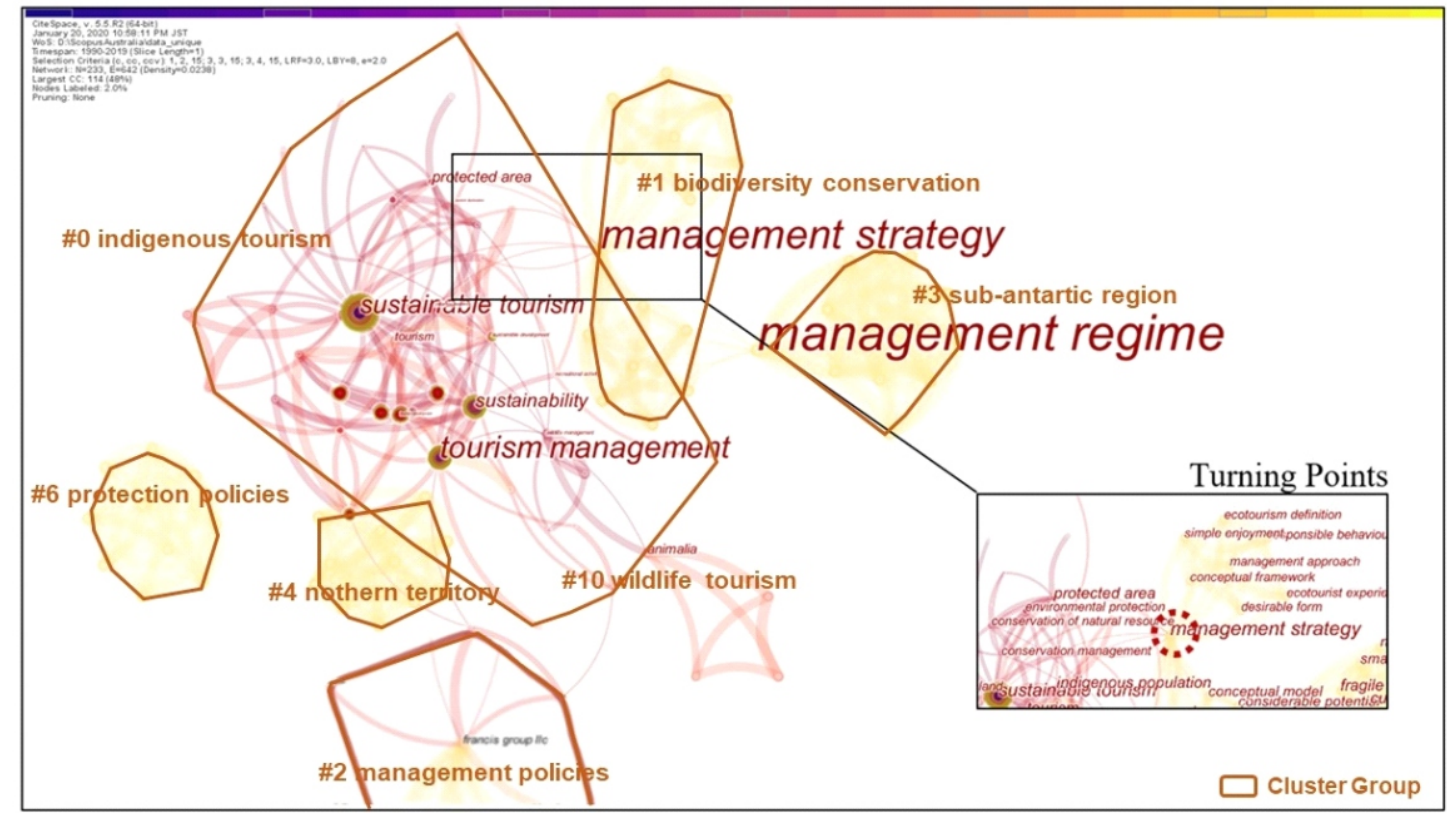

Figure 5 Co-occuring keywords and cluster labels of ecotourism policy in Australia.

Table 2 Cluster information for ecotourism research trend in Indonesia

\begin{tabular}{|c|c|c|c|c|c|}
\hline $\begin{array}{l}\text { Cluster- } \\
\text { ID }\end{array}$ & Cluster label & Size & Silhouette & $\begin{array}{l}\text { Mean } \\
\text { (Year) }\end{array}$ & Top 5 keywords \\
\hline$\# 0$ & Coast people & 31 & 0.695 & 2017 & $\begin{array}{l}\text { ecology, ecosystem, planning, community } \\
\text { participation, eco-tourism development }\end{array}$ \\
\hline$\# 1$ & $\begin{array}{l}\text { Community } \\
\text { based tourism }\end{array}$ & 27 & 0.825 & 2017 & $\begin{array}{l}\text { sustainable development, sustainable tourism, tourism } \\
\text { development, sustainable tourism development, }\end{array}$ \\
\hline \#2 & $\begin{array}{l}\text { sumatran } \\
\text { elephant }\end{array}$ & 19 & 0.812 & 2017 & $\begin{array}{l}\text { coastal community, development strategy, laws and } \\
\text { legislation, economic activity, employment } \\
\text { opportunity }\end{array}$ \\
\hline$\# 3$ & $\begin{array}{l}\text { Branding } \\
\text { strategy }\end{array}$ & 19 & 0.892 & 2017 & $\begin{array}{l}\text { local community, coastal ecosystem, tourist } \\
\text { destination, east nusa tenggara, coral reef }\end{array}$ \\
\hline \#4 & Whale shark & 18 & 0.955 & 2011 & $\begin{array}{l}\text { ecotourism industry, bajo fishermen, cetacea, } \\
\text { customary belief, long-lived migratory specy, }\end{array}$ \\
\hline \#6 & Data collection & 15 & 0.904 & 2016 & $\begin{array}{l}\text { ecotourism, tourist attraction, tourism, data } \\
\text { acquisition, data analysis }\end{array}$ \\
\hline \#7 & Mangrove area & 8 & 0.968 & 2008 & $\begin{array}{l}\text { biodiversity, agricultural management, cropping } \\
\text { practive, alternative agriculture, computer simulation }\end{array}$ \\
\hline
\end{tabular}

Table 3 Cluster information for ecotourism research trend in Japan

\begin{tabular}{|c|c|c|c|c|c|}
\hline Cluster-ID & Cluster label & Size & Silhouette & $\begin{array}{r}\text { Mean } \\
\text { (Year) }\end{array}$ & Top 5 keywords \\
\hline$\# 0$ & Fengshui forest & 41 & 1 & 2014 & $\begin{array}{l}\text { biodiversity, conservation, china, community } \\
\text { forestry, far east, }\end{array}$ \\
\hline$\# 1$ & $\begin{array}{l}\text { Resident } \\
\text { empowerment }\end{array}$ & 24 & 0.935 & 2012 & $\begin{array}{l}\text { sustainability, heritage tourism, cultural heritage, } \\
\text { sustainability of cultural heritage, spatial } \\
\text { econometrics }\end{array}$ \\
\hline$\# 2$ & $\begin{array}{l}\text { Advantageous } \\
\text { cluster }\end{array}$ & 22 & 1 & 2015 & $\begin{array}{l}\text { Hokkaido, destination management, policy } \\
\text { development, tourist satisfaction, economic impact }\end{array}$ \\
\hline$\# 3$ & Tourism industry & 20 & 0.979 & 2016 & $\begin{array}{l}\text { group size, Japan, dolphin tourism, cetacea, } \\
\text { Amakusa Island }\end{array}$ \\
\hline \#6 & $\begin{array}{l}\text { Participatory } \\
\text { conservation }\end{array}$ & 12 & 0.956 & 2013 & $\begin{array}{l}\text { participatory approach, khojir national park, bottom } \\
\text { up management, conservation management, local } \\
\text { people }\end{array}$ \\
\hline \#11 & $\begin{array}{l}\text { Nature-based } \\
\text { tourism }\end{array}$ & 6 & 0.976 & 2003 & $\begin{array}{l}\text { coastal zone, primate, industrial application, } \\
\text { environmental impact, environmental protection }\end{array}$ \\
\hline
\end{tabular}


the most significant cluster, containing 31 nodes of cooccurrence keywords, and despite its lowest silhouette score (0.695), it still has good homogenous and consistency (Table 2). The highest silhouette score was obtained by Cluster \#7 Mangrove Area, which is affected by the size so that it has higher homogeneity and consistency. Most research studies in Cluster \#0 Coastal People have been focused on mangrove ecotourism and management (Arkwright \& Kaomaneng, 2018; Feti \& Hadi Sudharto, 2018; Harahab et al., 2018; Idajati \& Widiyahwati, 2018; Indah et al., 2018; Prasetya et al., 2018; Prasetyo et al., 2018; Roziqin, 2018).

Based on the mean year information, the topic trends of ecotourism policy research in Indonesia shifted from mangrove area (2008) to whale shark (2011), data collection (2016), coast people, community based tourism, sumatran elephant, and branding strategy (2017). Unlike the other countries, Indonesia cluster distributions overlap with each other in recent studies. Taking into account that the number of ecotourism-related publications increased significantly in 2017 , this overlap may be due to the emergence of various interesting topics for researchers in ecotourism policy. These overlapping clusters may indicate the wide range of research subjects examined in ecotourism policy research in Indonesia, which is positive, or the overlap may also reflect the problem of overlapping management in Indonesia (Meilani \& Muntasib, 2013; Nasution et al., 2018).

Similar to Indonesia, six clusters were identified for the ecotourism policy research trend in Japan. They are a) Fengshui Forest, b) Resident Empowerment, c) Advantageous Cluster, d) Tourism Industry, e) Participatory Conservation, and f) Nature-based Tourism, as shown in Figure 3. Most of the silhouette scores in this cluster analysis were close to 1 (Clusters $1,3,6$, and 11) or were equal to 1 (Clusters 0 and 2). Therefore, all of the clusters have good properties of homogeneity and consistency.

The most significant cluster in this result is Cluster \#0 Fengshui Forest, containing 41 nodes of keywords (Table 3 ). The top five keywords of this cluster not only include China and the Far East (China, Japan, and other countries in eastern
Asia) but also biodiversity, and conservation. As can be seen from the definition, the Fengshui forest is generally the cultural preservation area of the natural landscape in China, which is also common in other parts of Asia, such as Korea and Japan (Chen et al., 2018). Thus, Cluster \#0 Fengshui Forest label covers the ideas of biodiversity and conservation in the Far East. This forest concept is particularly meaningful for supporting the present efforts of the national government to contribute to urban forestry, ecosystem conservation, cultural heritage preservation, and ecotourism (Chen et al., 2018).

Another impressive cluster in this result is Cluster \#1 Resident Empowerment, considering the variety in this research timeline. As shown by the various colors ranging from dark blue to yellow, the research on these topics has been continuously conducted since the first research recorded in the database until recent years (2003-2017). Resident empowerment has been believed to be the main principle of sustainable tourism development (Boley \& McGehee, 2014). Such tourism is mostly ecotourism, whereas empowerment defined as transformation growth of people from vulnerable conditions to a condition of having their power to manage their life and environment (Sadan, 1997).

Most studies have focused on cultural and heritage such issues as the relationship between the cultural heritage and tourism (Loulanskia \& Loulanski, 2011), cultural-based perception of resident empowerment (Maruyama et al., 2016), integration of cultural and natural resource into tourism supply (Romão et al., 2017), and cultural-tourism development centered on the World Heritage sites (Yamamura, 2003).

Based on the mean year information, the topic of ecotourism policy research in Japan shifted from Naturebased tourism (2003), to Resident empowerment (2012), Participatory conservation (2013), Fengshui forest (2014), Advantageous cluster (2015), and Tourism industry (2016). This trend shows the main topics of ecotourism research in Japan but does not eliminate the possibility that the other research topics were also investigated in another timeline.

Table 4 Cluster information for ecotourism research trend in Australia

\begin{tabular}{|c|c|c|c|c|c|}
\hline $\begin{array}{l}\text { Cluster- } \\
\text { ID }\end{array}$ & Cluster Label & Size & Silhouette & $\begin{array}{l}\text { Mean } \\
\text { (Year) }\end{array}$ & Top 5 keywords \\
\hline$\# 0$ & $\begin{array}{l}\text { Indigenous } \\
\text { tourism }\end{array}$ & 44 & 0.892 & 2007 & $\begin{array}{l}\text { tourism management, sustainable tourism, } \\
\text { sustainability, protected area, tourism }\end{array}$ \\
\hline$\# 1$ & $\begin{array}{l}\text { Biodiversity } \\
\text { conservation }\end{array}$ & 15 & 0.974 & 1995 & $\begin{array}{l}\text { management strategy, interpretation, simple } \\
\text { enjoyment, conceptual model, management } \\
\text { approach, environmental education }\end{array}$ \\
\hline$\# 2$ & $\begin{array}{l}\text { Management } \\
\text { policies }\end{array}$ & 14 & 0.960 & 1999 & $\begin{array}{l}\text { tourist attraction, marine park, tourist behaviour, } \\
\text { ecotourism component, cultural dimension }\end{array}$ \\
\hline$\# 3$ & $\begin{array}{l}\text { Sub-antarctic } \\
\text { region }\end{array}$ & 13 & 0.967 & 1994 & $\begin{array}{l}\text { management regime, cultural heritage, managing } \\
\text { nature tourism, government authority, heritage }\end{array}$ \\
\hline$\# 4$ & Northern territory & 11 & 0.986 & 1994 & $\begin{array}{l}\text { aborigine, comanagement, cultural diversity, } \\
\text { australian national park, ethonecology }\end{array}$ \\
\hline$\# 6$ & $\begin{array}{l}\text { Protection } \\
\text { policies }\end{array}$ & 10 & 0.977 & 1993 & $\begin{array}{l}\text { future prospect, country ecotourism destination, } \\
\text { industry segment, client expectation, Australian } \\
\text { tourism }\end{array}$ \\
\hline$\# 10$ & Wildlife tourism & 7 & 0.976 & 2009 & $\begin{array}{l}\text { wildlife tourism, wildlife management, animalia, } \\
\text { cetacea, whale }\end{array}$ \\
\hline
\end{tabular}


In contrast to Indonesia and Japan, seven clusters were obtained for ecotourism policy research in Australia. They are a) Indigenous Tourism, b) Biodiversity Conservation, c) Management Policies, d) Sub-Antarctic Region, e) Northern Territory, f) Protection Policies, and g) Wildlife Tourism, as shown in Figure 5.

Cluster \#1, Indigenous Tourism, is the largest obtained cluster and has been a part of Australian ecotourism since the 1990s (Table 4), with 200 indigenous tourism businesses in Australia. Indigenous ecotourism refers to the involvement of indigenous people in nature-based ecotourism activities in their living environment, including their indigenous way interpretation of nature and culture, generally related to the Aborigine tribes. (Fennell \& Downling, 2003).

Comparison of ecotourism policy research trends Based on the co-occurrence keywords results, similar research trends between Japan and Indonesia were observed for some keywords such as "biodiversity" and "community" or "participatory approach" (Figure 6). Another similar research trend in Japan and Australia is sustainability. This comparison only includes five keywords with the highest betweenness centrality. Therefore, while more similar keywords may have been found, they have been excluded because they are not considered as the trend.

Keywords that characterize each county research trends are 'biodiversity' for Japan, 'conservation' for Indonesia and 'management' for Australia. Compared to other countries, ecotourism policy research trends in Indonesia are focused more on ecological conservation. Because Australia is a prosperous country, ecotourism research, there is more focused on "management." This is correlated with the fact that the Australian management system, based on accreditation and certification, can be a useful reference.

Research themes based on the cluster analysis between Japan, Indonesia, and Australia also show some similarities related to the co-occurrence keywords found. Japan and Australia have similar research themes of Biodiversity and Conservation, and Cultural and Heritage, while Japan and Indonesia have similar research themes of community-based ecotourism and conservation.
Research trends perspective and its relation to ecotourism policy The first glance based on the numbers of the study area shows that research on ecotourism conducted in Japan and Australia are more anthropocentric approaches as to how their most subject areas of the research are in Social Sciences. Meanwhile, Indonesia scholar studies ecotourism focuses on ecocentric approaches as the most subject areas are in Environmental Sciences. On the other hand, define judgment cannot only be based on the subject areas of the publication. Background studies of the researchers should also be the factors for these numbers. Therefore, from these research findings on keywords and themes are supposedly done to elaborate on the whole perspectives of these countries regarding ecotourism policy.

However, it does not necessarily mean that Japan's researcher did not pay attention to the environment. Biodiversity, as the most significant ideas on ecotourism for Japan scholars, believed to the essential for well-being, including human survival (Wearing \& Neil, 2009). Besides, the most significant cluster is the Fengshui forest, as a traditional ecological knowledge for biodiversity conservation in Japan, supported the ideas of both people and the environment that are equally important in ecotourism for Japan's researchers. Whereas, traditional ecological knowledge, which often falls into cultural-ecological studies, is an ethnological approach that sees the modes of production of societies around the world as an adaptation to their local environments (Berkes, 2012). As also mentioned in Japan's ecotourism policy, Ecotourism Promotion Act (2007), ecotourism should consider the conservation of biodiversity as well as contributing to the sound development of local communities and local economies, by appropriately implantation of coordination among various entities.

Australia's researchers, on the other hands, see that dealing with ecotourism can be simultaneously done by having the priority to the management, whereby all means, includes human, environments and its wildlife. Australian National Ecotourism Strategy (1994), has considered as the most excellent examples of policy development with stakeholder involvement in ecotourism, with the belief that growth and management of ecotourism are fundamental to

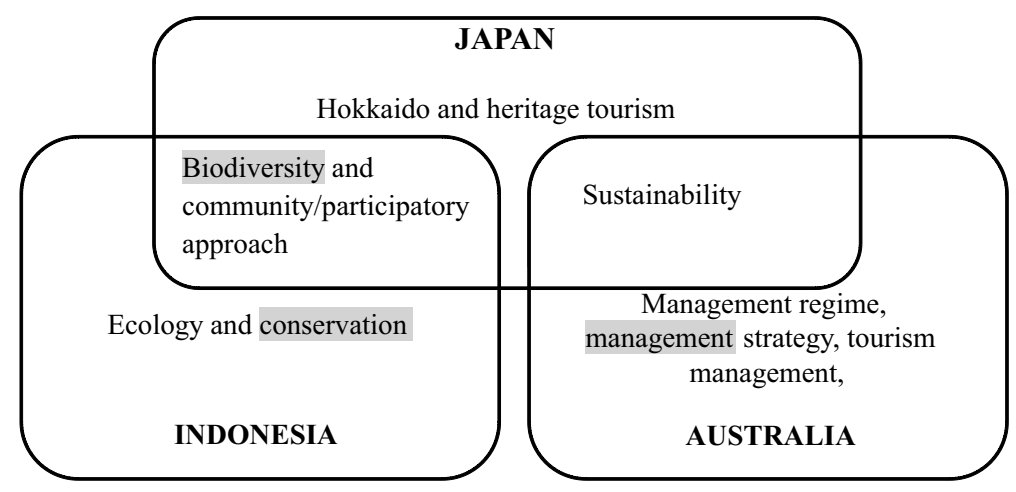

Figure 6 Comparison of keywords trends between countries. 
optimizing the benefits it offers (Fennell, 2015). This strategy consisted of 12 ecotourism strategy objectives, as follows: ecological sustainability integrated regional planning, natural resource management, regulation, impact monitoring marketing, industry standards/accreditation, education involve indigenous people, viability, and equity consideration (Grant, 1995). One of the objectives in these strategies, indigenous people, became the main theme of most researched in Australia, which is indigenous tourism.

Indonesia has one of the biggest tropical rainforest and marine resources in the world. No wonder if their highest priority is to protect their ecosystem. Moreover, as expected, this research results supported the idea of their preference in environments without leaving the importance of human life behind. It also fits in with policies in Indonesia to apply the ecotourism principles includes suitability, conservation, economy, educations, satisfaction, community participation, and traditional knowledge (Ministry of Home Affairs Indonesia, 2009). Overall, all priorities of approach could be the main factor of the different ecotourism policies in each country. The similarity of these countries is that they still keep the right balance between the environment and human life.

Regardless of how Japan's and Australia's research is social-oriented, it does not necessarily mean that Indonesia's policy should shift into social oriented. But still, they should consider enriching research about ecotourism policy from the social science point of view. Ecotourism is not solely on the environment because there is a robust interconnection between humans and their environment. Also, note that social science is a more dynamic topic compared to the environment topic meaning the necessities on this aspect are quite demanding.

Evolution of ecotourism policy according to bibliographic records The findings of this research show how trends shift from one to another time interval. Australia researchers were the first to take off in ecotourism policy history. Themes related to the policies were the earliest occur before the national policy in 1994 came out, shows that their most initial attention, in the mean year 1993, was to the policies and then actually the output of the national strategies itself. This policy indeed continues to develop and improve, starting from the expansion of standards, to the deepening of strategy. The evolution of ecotourism research in Australia changes as it needs to deal with ecotourism issues, from policy, conservation, and protection, and finally to management issues. The turning point of the ecotourism policy in Australia shows that management, which is also a result of trends, is the most influential in their policies.

Japan, which began its research in ecotourism policy a little bit late in 2003, also visualized the pattern of keywords networks in a natural movement flow. At the beginning of they focus on natural resources. Then, after their ecotourism policy came out in 2007, research soared and varied from the community, conservation, traditional knowledge to profits from the ecotourism industry.

The same pattern flow on the results of Australia and Japan did not happen to Indonesia. Their attention to ecotourism policies came later, causing overloaded issues raised at the same time. It is noticeable in the pattern of trend movements in Indonesia (Figure 3), which mostly emerged in 2017 (Table 2). This last-minute attention could also be one of the overlapping factors in policy and management in Indonesia. Also, the last ecotourism policy in Indonesia from the Ministry of Home Affairs was issued in 2009, and there is no track record of previous research. However, as mentioned earlier in the data collection section, it might have happened because of the limited ability of Indonesian researchers to publish the results in international journals with the Scopus Index. This problem is serious because although Indonesian journals currently have excellent research standards, it is most likely that before 2009 their publication standards for Indonesian journals were way from high.

Potential future research and recommendation One of the limitations of this research is the method that only relies on keyword analysis, which, of course, another research can develop using a more in-depth analysis method. Also, the limitations of the Scopus database for publication from Indonesia and Japan, indicate the potential for research using the same method but with the local journal database of each country.

Despite all those limitations, this study was able to find issues in the development of ecotourism policies in various countries. The approach and development process of ecotourism policy issues used by Australia, Japan, and Indonesia can contribute and be studied by researchers from particular countries and other countries.

One of the recommendations for policy in Indonesia is to revise the regulation on ecotourism development from the Ministry of Home Affairs Indonesia (2009). Likely, the basic research for the policy is still insufficient. Thus the implementation of their policy is less successful, as well as needs to be more enhance and developed. Also, the Indonesian government should clarify its goal for ecotourism so that later it can create clear movement patterns in research trends. This is then expected to improve overlapping conditions not only in research trends but also in ecotourism policies and management for real.

The concept of the local community's participatory approaches in ecotourism is similar between Indonesia and Japan, but in terms of implementation, there is a distinctiveness. Based on the similarity of the concept, it is likely beneficial for Indonesia to learn about the implementation of this participatory approach from Japan.

Finally, the authors consider this method can be beneficial to understand the broader context of problems in a country, especially if supported by comparing the results with other acknowledgeable countries. Because without comparing the result to the other countries, we cannot see the abnormality of the analysis result. Difficulties for this method include the interpretation of the keywords and trends, and understanding using the software.

\section{Conclusion}

This study examines the ecotourism policy research trends in Indonesia, Japan, and Australia based on the bibliographic records by using the scientometric approach. The number of articles and also the research themes are increased rapidly in recent years for Indonesia, while more steady for Japan and Australia. The result indicates that 
Australia is the leading country in this ecotourism policy research with the highest number of publications. The networks analysis pattern and research trend's evolution results suggested that the overlapping problem in Indonesia is due to the interrelated problem between the lack of research in ecotourism before their ecotourism policy made in 2009, and no clear goals for the ecotourism policy in Indonesia.

\section{Recommendation}

The ecotourism policy in Indonesia needs to be revised to clarify their goals for proper ecotourism implementation in Indonesia. Further, the research of the ecotourism policy research trend in Indonesia needs to cover research results published in Indonesian journals or in-depth analyses such as content analysis. At last, this paper provides at least the information for Indonesian researchers about potential research topics related to ecotourism policy in Japan and Australia.

\section{References}

Albort-Morant, G., Henseler, J., Leal-Millán, A., \& CepedaCarrión, G. (2017). Mapping the field: A bibliometric analysis of green innovation. Sustainability, 9(6), 1011. https://doi.org/10.3390/su9061011

Ariefianda, R., Hidayat, J. W., \& Maryono, E. (2019). Assessment of tourism suitability in natural tourism object of Lengkuas Island, Sijuk District, Belitung Regency, Bangka Belitung Province. E3S Web of Conferences, 125. https://doi.org/10.1051/e3sconf/2019 12501011

Arkwright, D., \& Kaomaneng, I. S. (2018). Mangrove ecotourism development on Kakaralamo Island North Halmahera: Community perception, participation and development strategies. IOP Conference Series: Earth and Environmental Science, 175(1). https://doi.org/10. $1088 / 1755-1315 / 175 / 1 / 012232$

Aryasa, A. M., Bambang, A. N., \& Muhammad, F. (2017). The study of environmental carrying capacity for sustainable tourism in Telaga Warna Telaga Pengilon Nature Park, Dieng Plateu, Central Java. IOP Conference Series: Earth and Environmental Science, 70(1). https://doi.org/10.1088/1755-1315/70/1/012003

Berkes, F. (2012). Sacred ecology: Traditional knowledge and resource management. Environmental Ethics, 22(4), 419-421. https://doi.org/10.5840/enviroethics20002247

Boley, B. B., \& McGehee, N. G. (2014). Measuring empowerment: Developing and validating the Resident Empowerment through Tourism Scale (RETS). Tourism Management, 45, 85-94. https://doi.org/10.1016/j.tour man.2014.04.003

Ceballos-Lascurain, H. (1996). Tourism, ecotourism, and protected areas: The state of nature-based tourism around the world and guidelines for its development. Gland: IUCN https://doi.org/10.2305/IUCN.CH.1996. 7.en
Chen, B., Coggins, C., Minor, J., \& Zhang, Y. (2018). Fengshui forests and village landscapes in China: Geographic extent, socioecological significance, and conservation prospects. Urban Forestry and Urban Greening, 31, 79-92. https://doi.org/10.1016/j.ufug. 2017.12.011

Chen, C. (2006). CiteSpace II: Detecting and visualizing emerging trends and transient patterns in scientific literature. Journal of the American Society for Information Science and Technology, 57(3), 359-377. https://doi.org/10.1002/asi.20317

Chen, C. (2012). Predictive effects of structural variation on citation counts. Journal of the American Society for Information Science and Technology, 63(3), 431-449. https://doi.org/10.1002/asi.21694

Chen, C. (2018). Visualizing and exploring scientific literature with CiteSpace. CHIIR '18: Proceedings of the 2018 Conference on Human Information Interaction \& Retrieval (pp.369-370). https://doi.org/10.1145/31763 49.3176897

Chen, C., Dubin, R., \& Kim, M. C. (2014). Orphan drugs and rare diseases: A scientometric review (2000-2014). Expert Opinion on Orphan Drugs, 2(7), 709-724. https://doi.org/10.1517/21678707.2014.920251

Chen, C., Hu, Z., Liu, S., \& Tseng, H. (2012). Emerging trends in regenerative medicine: A scientometric analysis in CiteSpace. Expert Opinion on Biological Therapy, 12(5), 593-608. https://doi.org/10.1517/14712598.2012. 674507

Chen, C., McCain, K., White, H., \& Lin, X. (2005). Mapping scientometrics (1981-2001). Proceedings of the American Society for Information Science and Technology, 39(1), 25-34. https://doi.org/10.1002/meet. 1450390103

Chen, C., \& Morris, S. (2003). Visualizing evolving networks: Minimum spanning trees versus Pathfinder networks. Proceedings-IEEE Symposium on Information Visualization, INFO VIS, 67-74. https://doi.org/10.1109/ INFVIS.2003.1249010

Chen, H., Feng, Y., Li, S., Zhang, Y., \& Yang, X. (2019). Bibliometric analysis of theme evolution and future research trends of the type a personality. Personality and Individual Differences, 150, 109507. https://doi.org/10. 1016/J.PAID.2019.109507

Chin, C. L. M., Moore, S. A., Wallington, T. J., \& Dowling, R. K. (2000). Ecotourism in Bako National Park, Borneo: Visitors' perspectives on environmental impacts and their management. Journal of Sustainable Tourism, 8(1), 20-35. https://doi.org/10.1080/09669580008667347

de Toledo, R. F., Miranda Junior, H. L., Farias Filho, J. R., \& Costa, H. G. (2019). A scientometric review of global research on sustainability and project management dataset. Data in Brief, 25. https://doi.org/10.1016/j.dib. 


\subsection{2}

Fennell, D. A. (2015). Ecotourism (4th ed.). London and New York: Routledge.

Fennell, D. A., \& Downling, R. K. (2003). Ecotourism policy and planning. London: CAB International.

Feti, F., \& Hadi Sudharto, P. (2018). The problem and its impacts of mangrove rehabilitation in Karangsong. E3S Web of Conferences, 73. https://doi.org/10.1051/e3sconf/ 20187304016

Fukamachi, K. (2017). Sustainability of terraced paddy fields in traditional satoyama landscapes of Japan. Journal of Environmental Management, 202, 543-549. https://doi.org/10.1016/j.jenvman.2016.11.061

Grant, J. (1995). The national ecotourism programme: Australia. Tourism Recreation Research, 20(1), 56-57. https://doi.org/10.1080/02508281.1995.11014735

Guo, D., Chen, H., Long, R., Lu, H., \& Long, Q. (2017). A coword analysis of organizational constraints for maintaining sustainability. Sustainability, 9(10), 1928. https://doi.org/10.3390/su9101928

Harahab, N., Riniwati, H., \& Abidin, Z. (2018). The vulnerability analysis of mangrove forest status as a tourism area. Ecology, Environment and Conservation, 24(2), 968-975.

Higuchi, Y., \& Yamanaka, Y. (2019). The potential value of research-based evidence in destination management: The case of Kamikawa, Japan. Tourism Review, 74(2), 173-185. https://doi.org/10.1108/TR-11-2017-0188

Hossard, L., \& Chopin, P. (2019). Modelling agricultural changes and impacts at landscape scale: A bibliometric review. Environmental Modelling and Software, 122. https://doi.org/10.1016/j.envsoft.2019.104513

Idajati, H., \& Widiyahwati, M. (2018). The sustainable management priority of ecotourism mangrove Wonorejo, Surabaya-Indonesia. IOP Conference Series: Earth and Environmental Science, 202(1). https://doi.org/10.1088/ $1755-1315 / 202 / 1 / 012048$

Indah, P. N., Radianto, I., Abidin, Z., Amir, I. T., \& Pribadi, D. U. (2018). Management mangrove experiences form coastal people. Journal of Physics: Conference Series, 953(1). https://doi.org/10.1088/1742-6596/953/ $1 / 012241$

Loulanskia, T., \& Loulanski, V. (2011). The sustainable integration of cultural heritage and tourism: A metastudy. Journal of Sustainable Tourism, 19(7), 837-862. https://doi.org/10.1080/09669582.2011.553286

Martinez, S., Delgado, M. del M., Martinez Marin, R., \& Alvarez, S. (2019). Science mapping on the environmental footprint: A scientometric analysis-based review. Ecological Indicators, 106. https://doi.org/10. 1016/j.ecolind.2019.105543

Maruyama, N. U., Woosnam, K. M., \& Boley, B. B. (2016). Comparing levels of resident empowerment among two culturally diverse resident populations in Oizumi, Gunma, Japan. Journal of Sustainable Tourism, 24(10), 1442-1460. https://doi.org/10.1080/09669582.2015. 1122015

Meilani, R., \& Muntasib, E. K. H. (2013). The role of ministry of internal affairs in ecotourism development in Indonesia. Media Konservasi, 18(3). https://doi.org/10. 29243/medkon.18.3.

Miller, K. J., Mundy, C. N., \& Chadderton, W. L. (2004). Ecological and genetic evidence of the vulnerability of shallow-water populations of the stylasterid hydro coral Errina novaezelandiae in New Zealand's fiords. Aquatic Conservation: Marine and Freshwater Ecosystems, 14(1), 75-94. https://doi.org/10.1002/aqc.597

Min, K., Yoon, M., \& Furuya, K. (2019). A comparison of a smart city's trends in urban planning before and after 2016 through keyword network analysis. Sustainability, 11(11). https://doi.org/10.3390/su11113155

Ministry of Home Affairs Indonesia. (2009). The guidelines for regional ecotourism development. Jakarta: Republic of Indonesia.

Murdiyarso, D., Purbopuspito, J., Kauffman, J. B., Warren, M. W., Sasmito, S. D., Donato, D. C., ..., \& Kurnianto, S. (2015). The potential of Indonesian mangrove forests for global climate change mitigation. Nature Climate Change, 5(12), 1089-1092. https://doi.org/10.1038/ncli mate 2734

Mustika, P. L. K., Welters, R., Ryan, G. E., D'Lima, C., Sorongon-Yap, P., Jutapruet, S., \& Peter, C. (2017). A rapid assessment of wildlife tourism risk posed to cetaceans in Asia. Journal of Sustainable Tourism, 25(8), 1138-1158. https://doi.org/10.1080/09669582.2016. 1257012

Nasution, R. H., Avenzora, R., \& Sunarminto, T. (2018). The analysis of ecotourism laws and policies in Indonesia. Media Konservasi, 23(1), 9-17.

Neuts, B., Romão, J., Nijkamp, P., \& Shikida, A. (2016). Market segmentation and their potential economic impacts in an ecotourism destination: An applied modelling study on Hokkaido, Japan. Tourism Economics, 22(4), 793-808. https://doi.org/10.1177/ 1354816616654252

Orams, M. B. (1996). A conceptual model of tourist-wildlife interaction: The case for education as a management strategy. Australian Geographer, 27(1), 39-51. https:// doi.org/10.1080/00049189608703156

Orams, M. B., \& Hill, G. J. E. (1998). Controlling the 
ecotourist in a wild dolphin feeding program: Is education the answer? Journal of Environmental Education, 29(3), 33-38. https://doi.org/10.1080/0095 8969809599116

Prasetya, J. D., Maharani, Y. N., \& Rahatmawati, I. (2018). Mangrove ecotourism management at local community in Jangkaran, Kulonprogo, using hierarchy analysis. IOP Conference Series: Earth and Environmental Science, 212(1). https://doi.org/10.1088/1755-1315/212/1/0120 06

Prasetyo, J. B., Muhammad, F., \& Sugianto, D. N. (2018). An overview of encouraging sustainable tourism in the coastal tourism of Karang Jahe Beach: Issues and challenges. E3S Web of Conferences, 73. https://doi.org/ $10.1051 / \mathrm{e} 3$ sconf/20187302015

Romão, J., Guerreiro, J., \& Rodrigues, P. M. M. (2017). Territory and sustainable tourism development: A spacetime analysis on european regions. Region, 4(3), 1-17. https://doi.org/10.18335/region.v4i3.142

Romão, João, Neuts, B., Nijkamp, P., \& Shikida, A. (2014). Determinants of trip choice, satisfaction and loyalty in an ecotourism destination: A modelling study on the Shiretoko Peninsula, Japan. Ecological Economics, 107, 195-205. https://doi.org/10.1016/j.ecolecon.2014. 07.019

Roziqin, A. (2018). Environmental Policy of Mangroves Management in Rembang Regency. E3S Web of Conferences, 31. https://doi.org/10.1051/e3sconf/20183 109002

Sadan, E. (1997). Empowerment and community planning. Hakibbutz Hameuchad Publishing, 350. Retrieved from http://scholar.google.com/scholar?q=intitle:Empowerm ent+and+Community+Planning\#7
Sasana, H., Nurcahyanto, H., \& Novitaningtyas, I. (2019). The development strategy of world heritage tourism in Indonesia. African Journal of Hospitality, Tourism and Leisure, 8(5).

Schianetz, K., Jones, T., Kavanagh, L., Walker, P. A., Lockington, D., \& Wood, D. (2009). The practicalities of a learning tourism destination: A case study of the Ningaloo Coast. International Journal of Tourism Research, 11(6), 567-581. https://doi.org/10.1002/ jtr.729

Sri Budhi, M. K., \& Lestari, N. P. N. E. (2016). Community based ecotourism development in Jatiluwih Village Bali. International Journal of Applied Business and Economic Research, 14(3), 1864-1880.

[TIES] The International Ecotourism Society. (2016). What is ecotourism? Retrieved from https://www.ecotourism. org/what-is-ecotourism

Turton, S. M. (2005). Managing environmental impacts of recreation and tourism in rainforests of the wet tropics of Queensland World Heritage area. Geographical Research, 43(2), 140-151. https://doi.org/10.1111/j.17 45-5871.2005.00309.x

Wardani, M. P., Fahrudin, A., \& Yulianda, F. (2017). Analysis of successful strategy to develop sustainable marine ecotourism in Gili Bawean Island, Gresik, East Java. IOP Conference Series: Earth and Environmental Science, 89(1). https://doi.org/10.1088/1755-1315/89/1/012036

Wearing, S., \& Neil, J. (2009). Ecotourism: Impacts, potentials and possibilites. Elsevier Ltd (2nd ed). Oxford: Elsevier Ltd.

Yamamura, T. (2003). Indigenous society and immigrants: Tourism and retailing in Lijiang, China, a world heritage city. Tourism, 51(2), 215-234. 